"Urban Myth of the New Contemporary Chinese City”, Journal of Architectural Education, Issue 63:2. 2009

\title{
Shenzhen: Urban Myth of a New Chinese City
}

Juan Du

The University of Hong Kong

Proximity to Hong Kong is often cited as the main reason for the economic success of Shenzhen and its surrounding Pearl River Delta region. Ironically, when Hong Kong was ceded by Qing Dynasty China to the British Empire in 1842, the then barren rock's biggest asset was its location in the Pearl River estuary, where the freshwater Pearl River flows into the South China Sea. The Pearl River Delta (PRD), located in China's southernmost Guangdong Province, was one of Asia's main trading ports for hundreds of years before the colonization of Hong Kong: there are sites within Shenzhen's urban territory that date to 300 C.E. From open trade, warring concessions, collapse of the Qing Dynasty, to the People's Republic of China's isolationist stance and later changing to the Open Door Policy reforms during the 1970s and 80s, the region has undergone tremendous transformations. The PRD is now home to about 45 million residents and currently a reported GDP of US\$ 300 billion, approximately $10 \%$ of China's national GDP. ${ }^{\text {i }}$ Certainly the PRD's rapid development since the 80s into China's major economic powerhouse is built upon its multifaceted economic and sociopolitical ties to Hong Kong, now China's Special Administrative Region since the hand-over in 1997. The creation of Shenzhen and other Special Economic Zones in 1979 adjacent to Hong Kong's territory was the first of many steps of China's experimentation with a capitalistic economy, albeit qualified with "socialist characteristics". These days proximity to Shenzhen and the rest of the PRD is again an adage that Hong Kong broadcasts to the world to stress its advantage in the global economy, releasing a hybrid label of the Greater Pearl River Delta.

More than perhaps any other city, Shenzhen has come to represent China's rapid modernization and urbanization, both in the international and domestic popular imagineire as well as recent scholarly work on modern China. Whether touting Shenzhen as the first Chinese city to be based on modern planning and its successful economic development, or dismissing it as a capitalist sweat-shop devoid of any local character, all seem to insist that Shenzhen is a city with "no-history" that came from "nothing" just a "sleepy" "fishing village" and "rice fields" consisting of "ground zero" development and then transformed "overnight" into an "instant city" with "no intermediary" stages. ii Ironically in an age of globalization devoid of ideological and spiritual sentiments, Shenzhen however, is often cited as a modern miracle. Certainly based upon all economic indicators and the popular visual representations, Shenzhen seems to be a city with standard modern qualities that transformed from the "land of fish and rice" into its glittering present form all within two decades. From an urban planning point of view, Shenzhen's first and successive Comprehensive Master Plans are based on classical Soviet-influenced centrally controlled master planning. The rigid formal planning resulted in an essentially linear city along a single coastal transportation spine named 
Shennan Grand Boulevard. The original 1986 Master Plan of Shenzhen Special Economic Zone planned for a population of one million by the year 2000. The 1989 Comprehensive General Planning Modification of Shenzhen Special Economic Zone tried to keep up with the faster than predicted growth by changing the planning to accommodate for 1.5 million residents. Yet, the population of Shenzhen stood at 10 million in 2000. ${ }^{\text {iii }}$ With such discrepancies between the centrally planned economy and urban form with the actual conditions of the city, how did Shenzhen not only survive, but reached such an economic success? The answer lies in the hidden urban realities of densely developed informal sites dubbed Cheng Zhong Cun, or "Villages in the City".

Take any satellite image of Shenzhen and examine areas along the very visible east-west transportation spine of Shennan Grand Boulevard, and you will notice that behind the layer of manicured roadside landscapes and towered developments there often exist blocks of densely packed gridded settlements. Venture inside these areas, and you encounter an entirely different urban condition than the typical images of Shenzhen: midrise high-density buildings within breathing room of each other. (See Figure 1) The existing 300 or so Villages are home to nearly half of Shenzhen's population, all packed into a total area of less than $10 \%$ of the city's land. People usually refer to these areas as "slums", "red light districts", or according to Shenzhen Municipality Villages in the City Reformation Declaration in 2005, "ulcers in our healthy urban environment". ${ }^{\text {iv }}$ Merged and purged from nearly 2,000 former agrarian villages that occupied the city's land prior to its re-birth and re-naming as Shenzhen, today there are about 300 such sites scattered throughout Shenzhen's commercial developments and industrial zones. In order to build the Shenzhen Special Economic Zone in 1989, the central government purchased the land rights from the village collectives by designating the land as urban and therefore owned exclusively by the central government. In exchange, each male villager received a $120 \mathrm{~m}^{2}$ parcel of land for private use to construct a new house. Over the following years, most villagers constructed low-quality and low-rent housing on these square parcels of land to take advantage of the massive influx of migrant workers who came to Shenzhen in search of work. The city's economic and spatial planning simply did not predict and could not construct enough housing for the sudden and continuous influx of migrants. Most of the former farmers became landlords and developers reaping steady income from the rents paid by these new comers to the city. In recent years, most of the former village heads have become CEOs of village-collective-owned corporations that develop commercial properties open to the public and negotiate enormous transactions by selling the villagecollective land to private investors and developers. In addition to housing, the Villages in the City are choked full of street side stands, small shops, open-air markets, all night games parlors, and underground factories. The Villages in the City often have unlicensed schools, clinics and hospitals, as migrant workers and their children are usually not eligible for the city's public facilities.

As the current Villages in the City are transformed from the original 'natural villages', the spatial relationships between sites are based on walking accessibility. The resulting urban organization is such that they are distributed throughout the city's many commercial centers. Most residents living in the Villages simply walk to work. With such inflexible linear transportation planning, having already met its capacity, it is difficult to 
imagine the consequences of all workers having to commute to work even on public transportation. In essence, these Villages in the City have become providers of affordable housing, close-knit social networks, and mixed-use developments, making up for what the central planning dangerously lacked: a sustainable socioeconomic urban fabric for the most basic forms of people's needs. (See Figure 2) Unquestionably the village and the city have always existed in codependence. Traditionally, the interchange is agricultural goods for monetary compensation. Yet, under the current conditions in China, the former codependence has been transformed into an unprecedented exchange and confrontation of complex social, economic, and political relationships. Discourse on modern China cannot ignore the massive floating rural population living and working within the city: the total number of the floating migrant population nationwide is estimated at 200 million, or a full $15 \%$ of China's total population. Exploration of the new Chinese city must also examine the social, economic, and political relationships between the Village and the City. In most Chinese cities today, the most basic needs - from shelter construction to food preparation - are met by migrant workers with no official status in the cities. This current phenomenon of inter-dependency between village and city is perhaps the most extreme in the case of Shenzhen. Demonizing these Villages in the City as "ulcers" and dismissing the unique history of Shenzhen as a whole is a gross oversight of a powerfully unique urbanization process. Not recognizing the historical significance of Shenzhen's past and present would lead to a missed opportunity to learn from such a sweeping, although unplanned, urban experimentation at a massive scale. Shenzhen, examined as China's accidental invention toward a radical hybrid urban structure could serve as a conceptual model for sustainable urban development in the Greater Pearl River Delta region and around the world.

Juan Du is Assistant Professor in the Department of Architecture at the University of Hong Kong and has taught architecture and urban design at Massachusetts Institute of Technology and the Graduate Center of Architecture at Peking University. She is founder of IDU_Architecture with projects ranging from architectural design to urban research and planning, engaging the field from the extents of the built form to the social processes of the city. Juan Du is the recipient of a Fulbright Fellowship for research on urban transformations of the contemporary Chinese city.

\footnotetext{
${ }^{\mathrm{i}}$ Statistics based on official Yearbooks published at the National and Province level. However one characteristic of China's population and economic data is that they are not verifiable. For the purposes of this essay, they are ensured enough accuracy to give a correct understanding of the economic context.

${ }^{i i}$ Words in quotations are common descriptors of Shenzhen in almost all writings on the City. I have noted one specific example in previous writing. Juan Du, “Don’t Underestimate the Rice Fields,” in Urban Transformations (Berlin: Ruby Press, 2008)

iii Planning History of Shenzhen, Shenzhen Urban Planning Bureau published pamphlets, 2005-2008. Also refer to the official website of the Shenzhen Planning Bureau, in Chinese at http://www.szplan.gov.cn/main/index.shtml.

iv The government's changing positions in regard to the Villages in the City are outlined in more details in my text “Don't Underestimate the Rice Fields,” in Urban Transformations (Berlin: Ruby Press, 2008).
} 